Szendy Viktória Anna ${ }^{1}$

\title{
Az önkormányzati tüzoltóságok helye és szerepe a katasztrófavédelem rendszerében
}

\author{
The Location and Role of Local Fire Fighting \\ in the Emergency Protection System
}

\begin{abstract}
Absztrakt
A tanulmány bemutatja az önkormányzati tüzoltóságokat a katasztrófavédelem rendszerén belül. Kitér a müködésükre, felügyeletükre és ellenörzésükre, illetve a tevékenységük ellátásához szükséges képzésre. Bemutatja azt a finanszírozási rendszert, amelynek kétoldaliságából az önkormányzati tüzoltóságok kettössége fakad. Elemzi a katasztrófavédelem 2012. január 1-jével kialakított rendszerét, a katasztrófavédelmi besorolás rendjét, majd abból következően az önkormányzati tüzoltóságok tűzvédelemmel és tüzmegelözéssel kapcsolatos feladatait.
\end{abstract}

Kulcsszavak: katasztrófavédelem, önkormányzati tüzoltóság, munka, felügyelet, oktatás, finanszírozás

\section{Abstract}

This article present the role and tasks of the municipal fire brigades inside the system of the disaster managment, onto them working with a strange look, their supervision and their cheque, their activity is necessary to his supply concerned onto a training, and the financing system from the bilateral of which the municipal fire brigades' duality stems. It analyzes the system of disaster management as of January 1, 2012, the order

Pest Megyei Katasztrófavédelmi Igazgatóság, előadó - Disaster Managment of Pest County, e-mail: ria.szendy@gmail. com, ORCID: 0000-0001-6140-3469 
of the disaster management classification, and consequently the tasks of municipal fire brigades related to fire protection and fire prevention, not the characteristics of their activities as public administration bodies.

Keywords: disaster managment, municipal fire brigade, working, supervison, instruction, financing

A tűzoltóságok helye és szerepe rendkívül meghatározó a rendvédelemben, hiszen a közigazgatás - és így a védelmi igazgatás - területén az egyik legalapvetőbb jog, a biztonsághoz való jog egyik eleme.

Magyarországon különböző „típusú” tűzoltóságok müködnek: hivatásos, önkormányzati, létesítményi és önkéntes.

Ezek tevékenységében, bár számos dologban eltérnek egymástól, a legfontosabb különbség a fenntartó „személyét” illeti, hiszen a hivatásos tűzoltóságok esetén az állam, az önkormányzatiaknál elsősorban az önkormányzat, létesítményinél az érintett létesítmény a fenntartó, az önkéntes tüzoltó egyesületek pedig elsősorban önfenntartók. ${ }^{2}$

A következőkben a katasztrófavédelem - tüzvédelmet is érintő - veszélyelhárítási tervezési rendszerét mutatom be, majd az önkormányzati tűzoltóságok katasztrófavédelemben betöltött szerepének rövid elemzéséből kiindulva azok múködését, a rájuk vonatkozó legfontosabb szervezeti eljárási elöirásokat ismertetem. A tanulmány egyik eleme a tűzvédelem hazai rendszerével és a fegyveres összeütközések időszakában (háborús) jelentkező tűzvédelem sajátosságaival foglalkozó tudományos kutatómunkámnak, így további tanulmányaim mind a hivatásos, mind pedig az önkormányzati, létesítményi és önkéntes tủzoltóságok ez irányú feladatait elemzik.

\section{A települések katasztrófavédelmi besorolásának jogszabályi alapjai}

Az egyes veszély-, illetve katasztrófahelyzetek hatékony megelőzése, az élet és anyagi javak megóvása érdekében 1995-ben először került sor hazánk településeinek polgári védelmi szempontú besorolására. A besorolás szabályait a települések polgári védelmi besorolásáról és a védelmi követelményekröl szóló 114/1995. (IX. 27.) Korm. rendelet határozta meg, amelynek megfelelöen négy csoportba lettek besorolva a települések.

Az azóta eltelt 12 év környezeti biztonságot befolyásoló eseményei, elsősorban a természeti eredetű veszélyforrások negatív megváltozása (például szélsőséges időjárási jelenségek egyre gyakoribbá válása), a lakosságot érintő új kockázatok beazonosítása szükségessé tette a korábbi besorolási rendszer felülvizsgálatát.

A 2010 októberében bekövetkezett vörösiszap-katasztrófa is alátámasztja az új megközelítés szükségességét, azt, hogy a települések besorolását az adott területre jellemző, valós kockázatbecslésen alapuló veszélyeztetettséghez kell igazítani. Ennek

Pályázatok révén segíti az önkéntes tüzoltó egyesület fennmaradását, müködését a hivatásos katasztrófavédelmi szerv, támogathatja az önkormányzat, magánszemélyek, civil szervezetek tevékenységét. 
érdekében olyan rugalmas szabályozást kell kialakítani, amely követi a természetes és épített környezetben bekövetkező változásokat.

A korábbi besorolási rendszer merev szabályozásával, az alapvetően honvédelmi (háborús) kockázatokra épülő veszélyeztetettségi rendszerével ellentétben a 2012. január 1-jén hatályba lépett, az egységes katasztrófavédelmi rendszert létrehozó jogszabályok, a katasztrófavédelemröl és a hozzá kapcsolódó egyes törvények módosításáról szóló 2011. évi CXXVIII. törvény (a továbbiakban: Kat.), valamint a Kat. végrehajtásáról szóló 234/2011. (XI. 10.) Korm. rendelet (a továbbiakban: Kat. vhr.) teljesen új alapokra helyezik a települések katasztrófavédelmi besorolásának szabályait. Elmondható, hogy a változtatások az elmúlt 12 év gyakorlati tapasztalatai alapján indokoltak voltak, napjainkra a katasztrófavédelem megújult, ehhez az Alaptörvénnyel összhangban kiadott Kat. hozzárendelte a jogszabályi alapot. ${ }^{3}$

A megújult szabályozás lényege, hogy minden egyes településre a valós helyi sajátosságokra jellemző veszélyeztető hatások felmérésével, az elvégzett egyedi kockázatbecsléssel kell a katasztrófavédelmi osztályba sorolást meghatározni. A Kat. vhr. meghatározza a kockázatbecslés fogalmát is, amely a kockázatazonosítás, a kockázatelemzés és a kockázatértékelés átfogó folyamatát jelenti.

A települések tủzvédelmének sajátosságaira, a hivatásos és a tanulmány szempontjából meghatározó önkormányzati tüzoltóságok feladataira tekintettel a következőkben bemutatom a települések katasztrófavédelmi osztályba sorolásának folyamatát, szabályait.

\section{Kockázatazonosítás, kockázatelemzés, kockázatértékelés}

A katasztrófák elleni védekezés egyik legfontosabb alappillére a megelőzés. A megelőzési és felkészülési feladatok fő célja a lakosság életét és anyagi javait veszélyeztető események bekövetkezési valószínüségének a lehető legkisebbre csökkentése, valamint a már bekövetkezett káresemények hatásainak minimalizálása, a károk hatékony elhárítása. Annak érdekében, hogy az ország teljes területén a megfelelő védelmi szint kialakítható legyen, a veszélyeztető hatások alapján kockázatbecslések elvégzése szükséges. A kockázatbecslési folyamat három lépésből tevődik össze, amelyek a következők:

a) kockázatazonosítás,

b) kockázatelemzés,

c) kockázatértékelés.

„Kockázatazonosítás: az az eljárás, amely meghatározza az adott területen lehetséges kockázatokat és azok hatásait, valamint magában foglalja a veszélyeztető hatások forrásának azonosítását. Az eljárás elvégzése során figyelembe kell venni a vizsgált területre vonatkozó statisztikai adatokat, történeti adatokat, tapasztalati tényeket, valamint a rendelkezésre álló kockázatelemzések eredményeit.

Muhoray Árpád: A katasztrófavédelem aktuális feladatai, Tanulmány, 2012, http://mhtt.eu/hadtudomany/2012/2012 elektronikus/2012_e_Muhoray_Arpad.pdf (Letöltve: 2018. 12. 10.) 
Kockázatelemzés: olyan eljárás, mely az adott területre vonatkozó azonosított lehetséges kockázatok csoportosítását és értékelését foglalja magában.

Kockázatértékelés: az az eljárás, mely a kockázatelemzés eredményeit felhasználva meghatározza az adott veszélyeztető hatás adott településre gyakorolt kockázati szintjét." ${ }^{\prime 4}$

Az elemzés tevékenység a döntés közvetlen lehetőségének biztosítása érdekében. A helyzet elemekre való bontását és az egyes elemek vizsgálatát jelenti a meghatározó okok és hatások felismerése céljából. Az elemzés végigkíséri az egész folyamatot. Szerepe kettős:

- módszeresen megismerni a helyzetet, annak fö vonásait, összefüggéseit és okokozati tényezőit,

- eljutni a megismerés olyan fokára, amikor már nemcsak a probléma megismerése, hanem a problémamegoldás változatai is kibontakoznak.

A katasztrófák elleni védelemben az elemzés a katasztrófavédelmi műveleti elgondolás (elhatározás) kialakításának felelősségteljes és döntő mozzanata, amelynek célja:

- a katasztrófavédelmi feladatok előkészítése és megoldása (végrehajtása) körülményeinek mindenoldalú tanulmányozása, értékelése gondos elemzések és számvetések alapján,

- és ezekre építve az alapvető következtetések levonása a feladatok leghatékonyabb megoldási módjainak meghatározása érdekében.

Az elemzés egyben a tárgyilagos - sokszor, ha kell, rideg - számvetések és az információk elfogulatlan feldolgozásának módszere is, amely vonatkozhat például a potenciális veszélyhelyzetek megítélésére éppúgy, mint a kétoldalú szerződésekre.

Fő feladata: mindazon tényezők számbavétele, amelyek a veszélyhelyzeteket jellemzik, és a szervezet előtt álló feladatok előkészítésére és végrehajtására - aktuálisan és hosszabb távra is - valamilyen hatást gyakorolnak vagy gyakorolhatnak.

Az elemzés nem cél, hanem eszköz, megfontoltan és a szükséges esetekben, mértékben kell igénybe venni. Az összefüggések feltárása során fontos követelmény:

- a tudomány igénybevétele,

- a tapasztalat és a gyakorlat tanulmányozása,

- a probléma reális és egyértelmủ megfogalmazása,

- a problémamegoldás erőforrás-szükségletének meghatározása,

- a várható eredmények és következmények feltárása, majd ezek következményeként konkrét cél és feladat megfogalmazása.

A célmeghatározás ugyanis a jó döntés nélkülözhetetlen feltétele, „tipikusan” és sajátosan vezetői (parancsnoki) feladat, akkor lehet jó, ha a meglévő - és elérhető - lehetőségekből indul ki és figyelembe veszi a felsőbb szervek előírásait is.

Az elemzés módszerei a feladatoktól és az egyes vezetési szintektől függően változnak, és alapvetően két csoportba sorolhatók: hagyományos (intuitiv értékelés),

234/2011. (XI. 10.) Korm. rendelet a katasztrófavédelemröl és a hozzá kapcsolódó egyes törvények módosításáról szóló 2011. évi CXXVIII. törvény végrehajtásáról. 
tudományos (leíró vagy normatív megközelítés, induktív vagy deduktív - összehasonlítás, azonosítás vagy minősítés). A kettő együttese meghatározó a vezetői (a parancsnoki) munka szempontjából, ugyanis az emberi ismeretanyag, tapasztalat mindig több, mint amennyit a tudomány már általánosított, az agyi intuitív folyamatokkal olyan bonyolult kérdéseket is meg lehet oldani, amit például technikai eszközökkel egyáltalán nem lehet megközelíteni.

A veszélyelemzés, a kockázatbecslés, a hatás- és biztonságvizsgálat alapvetően determinisztikus vagy valószínűségi megközelítésủ lehet:

- A determinisztikus megközelítés nem veszi közvetlenül figyelembe a lehetséges baleseti eseményláncok eltérő valószínűségeit, hanem a lehetséges veszélyekkel szemben biztonsági intézkedéseket követel meg, úgynevezett „nulla kockázatra” törekszik. A megkövetelt vizsgálatok ebben az esetben a veszélyek feltárásán kívül bizonyos biztonsági intézkedések, védelmi rendszerek és feltételek meglétét ellenőrzik, illetve a referencia-eseményláncokat és következményeket elemzik, azok valószínűségeinek számítása nélkül.

- A valószínűségi megközelítés ezzel szemben abból indul ki, hogy a kockázat nem csökkenthető nullára, és a számítások alapján kell eldönteni, hogy a vizsgált létesítmény müködéséből származó kockázat meghaladja-e a még elfogadható szintet, amelyet jogszabályok rögzítenek. Ebben az esetben az elemzés eszköze a mennyiségi kockázatbecslés, vagy más néven a valószínűségi hatásés biztonságelemzés.

A valószínűségi megközelítés módszereinek sorában sajátos ismeretanyagot jelent a kis valószínűségű események elemzésének módszertana, illetve a kockázatok elemzésének eljárásai. Ez utóbbi módszereket elterjedten alkalmazzák a műszaki életben a bonyolult rendszerek biztonságának elemzésére. A szélsőséges természeti jelenségek, folyamatok esetében azonban többnyire a bekövetkezés valószínüségi mérlegelésével foglalkoznak. A konkrét elemzési módszerek sorában a legismertebbek:

- a hibafaelemzés,

- az eseményfa-elemzés,

- a veszély- és működőképesség-vizsgálat (HAZOP-vizsgálat),

- és a mennyiségi kockázatbecslés különféle módszerei.

A hibafaelemzés célja: annak vizsgálata, hogy bizonyos "nemkíváNATOs események” (környezetveszélyeztetés, ipari baleset, üzemzavar) bekövetkezéséhez milyen meghibásodások, külső hatások, általánosságban milyen okok szükségesek. Ez a szemlélet deduktív, mert az okozat felől halad az okok irányába. Az elemzés keretében elöször a csúcseseményeket azonosítják, amelyek bekövetkezése esetén jelentős környezeti hatás, károsodás léphet fel. Ez a módszer alapvetően a súlyos balesetekkel foglalkozik, amikor - a SEVESO-irányelvek alapján - a létesítmény tervszerü múködésének olyan zavara következik be, hogy mérgezö, tüz- vagy robbanásveszélyes anyag vagy anyagok jelentős emisszió, tüz vagy robbanás következtében azonnal vagy későbbi időben, súlyos veszélyt idéznek elő. Súlyos veszélynek minősül: az emberi élet fenyegetettsége vagy súlyos egészségkárosodás lehetősége, egészségkárosodás lehetősége nagyobb létszámú embereknél, a környezet, különösen az állat- és növényvilág, a talaj, 
a földfelszíni és a felszín alatti vizek, a légkör károsodása, illetve a kulturális vagy egyéb javak károsodásának lehetősége.

Az elemzés lényege az oksági lánc „visszafejtése”. Az így elkészített hibafák minőségi elemzése során értékelni kell az alapesemények összes olyan kombinációit, amelyek a csúcseseményhez vezetnek. Értékelni kell azokat az eseménykombinációkat is, amelyek bekövetkezésének elkerülésével a csúcsesemény nagy valószínűséggel nem jöhet létre (ezek a „biztonság garanciáinak” nevezhetők). Abban az esetben, ha az alapeseményekre statisztikai (valószínűségi) adatok is rendelkezésre állnak, elvégezhető a hibafa mennyiségi elemzése (kiértékelése) is. A hibafaelemzés négy részből áll: a probléma definiálása, a hibafa megalkotása, a megoldása, valamint a minimális hibaesemény-kombinációk rendsorolása. ${ }^{5}$

Az eseményfa-elemzés - az előző módszerrel ellentétben - induktív szemléletű eljárás. Az okok felöl indulva, a lehetséges okozatok, következmények megkeresésére irányul. Az eseményfa kiinduló pontját kezdeti eseménynek nevezik és elemzik a további események bekövetkezésének lehetőségét, a különböző következményekkel járó és eltérő valószínűséggel bekövetkező eseményláncot. Az üzemzavarok és balesetek hatásainak feltárására ez az eljárás alkalmas, a lehetséges okok feltárására pedig a hibafa módszer használható, amely egyúttal a megtett és a megtehető biztonsági intézkedések elemzését is lehetővé teszi. Így tehát alkalmas „a lehetséges igénybevettséget, szennyezettséget és károsítást megelőző, csökkentő, illetve elhárító intézkedések meghatározására".

A biztonságelemzések elterjedt módja - elsősorban a vegyiparban - a veszélyés müködőképesség-vizsgálat (az úgynevezett HAZOP-vizsgálat). Ebben a megközelítésben nem érvényesülnek a valószínúségi vagy statisztikai meggondolások. A módszer önmagában is alkalmazható egy vegyi üzem lehetséges veszélyeinek feltárására, de számszerủ kockázatelemzés végzése előtt előzetes veszélyazonosításra, a későbbi elemzések során figyelembe veendő meghibásodási módok, alapesemények azonosítására is alkalmas.

Az előzők mellett elterjedt eljárásmód az összetett (integrált) veszélyelemzés és kockázatbecslés. Különböző formájú lehet, alapvetően három területet ölel fel: mátrixok felállítása, a kockázat és érzékenység feltérképezése, és a várható veszteség (gazdasági) összetett becslése.

Az összetett veszélyek elsőfokú elemzései egyszerü mátrixokkal végezhetők el. Ezek a megjelenítések: a helyi veszélyeket, a csökkentési reakciókat és a közreműködők (állami, közigazgatási, egyéb) közötti együttmüködési feladatokat („a közös dolgokat”) mutatják be. Ez azt jelenti tehát, hogy:

- információs szempontból kell elemezni a kritikus eseményt, eseményeket, azok hatásait és hatásainak következményeit;

- alapinformációkkal kell rendelkezni az állampolgár, a lakosság, a társadalom és intézményrendszere normálhelyzeti körülményeiről, életéről, életfeltételeiről, környezetéről és vagyoni helyzetéről;

Bognár Balázs et al.: Iparbiztonságtan I. Kézikönyv az iparbiztonsági üzemeltetői és hatósági feladatok ellátásához, Nemzeti Közszolgálati Egyetem, Budapest, 2013, 409.

6 6. számú melléklet a 314/2005. (XII. 25.) Korm. rendelethez, A környezeti hatástanulmány általános tartalmi követelményei, 6. a) pont. 
- információkkal kell rendelkezni a kritikus esemény, események bekövetkezésének lehetséges okairól;

- információkkal kell rendelkezni a katasztrófa elleni védekezés (megelőzés, védekezés, helyreállítás) szintenkénti rendszeréről;

- információkkal kell rendelkezni a vezetési szintenként megteendő intézkedésekröl;

- valamint információkkal kell rendelkezni a korábban megtörtént események hazai és nemzetközi tapasztalatairól.

A kockázat és érzékenység feltérképezése egy térképsort adhat, amely az elemzések alapján megadja a következőket:

- A kockázat, amelyet az összes lehetséges veszély okoz, az összes helyszínen és igazgatási területen belül: különböző erősségü szinteknél, elöfordulási valószínüségként kifejezve, és ha lehetséges, a két (vagy több) katasztrófa egyidejü előfordulásának valószínűsége.

- Az igazgatási területen belül a veszélyeknek kitett egyes területek érzékenysége: fizikai, természeti és gazdasági erőforrások valószínű károsodásának kifejezésében, az egyes erősségi szintű (fokozatú), egyes katasztrófákból következően.

A kockázatelemzés szempontrendszerében megjelenik:

- A kockázatok azonosítása: célja azoknak a veszélyeztető hatásoknak a meghatározása, amelyek hatással lehetnek az emberekre, környezetre. Többféle szempontból lehet vizsgálni a kockázatot, emberi, pénzügyi vagy környezeti, de a vizsgálat céljából föként az emberekre és a környezetre gyakorolt hatást célszerü figyelembe venni.

- Az azonosított kockázatok elemzése: a kockázatelemzés többféle, a fentebb bemutatott modellel elvégezhető. Figyelembe kell venni azt, hogy az egyes események milyen mértékben gyakorolnak hatást az ott élőkre.

- A kockázatértékelés: a kockázatértékelés során elemezni kell és meghatározni azt a kockázati szintet, amelyet a kockázatelemzés során feltártunk. A kockázatok megjelenítése kockázati mátrixon keresztül végeredményként, ha az lehetséges, akkor kockázati térképen történik meg.

- Az eredmények bemutatása kockázati mátrix struktúrában - lehetőség szerint térképi megjelenítéssel.

\section{Veszélyelhárítási tervezés}

Rendszerét, követelményeit a katasztrófavédelemről és a hozzá kapcsolódó egyes törvények módosításáról szóló 2011. évi CXXVIII. törvény végrehajtásáról szóló 234/2011. (XI. 10.) Korm. rendelet határozza meg. A veszélyelhárítási tervezés célja, hogy a természeti, civilizációs és egyéb eredetű veszélyekre a kockázatok azonosítása, elemzése és értelmezése alapján egységes okmányrendszerbe foglalja a katasztrófavédelmi 
feladatok és intézkedések rendjét, végrehajtását, valamint az azt biztosító személyi, anyagi és technikai eszközök hozzárendelését. A veszélyelhárítási tervezés szintjei:

- munkahelyi veszélyelhárítási terv,

- települési (a fővárosban kerületi) veszélyelhárítási terv (a továbbiakban együtt: települési veszélyelhárítási terv),

- a katasztrófavédelmi kirendeltség összesített terve,

- területi (fővárosi) veszélyelhárítási terv,

- központi veszélyelhárítási terv.

- veszélyelhárítási feladatterv.

A tervkészítésre kötelezettek veszélyelhárítási terveiket folyamatosan naprakészen tartják.

\section{Munkahelyi veszélyelhárítási terv}

A hatósági határozattal kijelölt gazdálkodó szerv munkahelyi veszélyelhárítási tervet készít a gazdálkodó szerv területén munkát végzők és az egyéb okból ott tartózkodók védelmére. Mentesül a munkahelyi veszélyelhárítási terv készítése alól a belső védelmi tervet, súlyos káresemény-elhárítási tervet készítő gazdálkodó szerv. A hatósági határozattal kijelölt gazdálkodó szervek a telephely környezetét veszélyeztető hatásokról adatokat szolgáltatnak a települési veszélyelhárítási terv készítéséhez a polgármester számára. A munkahelyi veszélyelhárítási tervet a gazdálkodó szerv vezetője hagyja jóvá a katasztrófavédelmi kirendeltség egyetértésével.

\section{Települési veszélyelhárítási terv}

Települési veszélyelhárítási tervet készít a polgármester a katasztrófavédelmi szempontból osztályba sorolt településeken a katasztrófavédelmi kirendeltség közreműködésével. A települési veszélyelhárítási terv alapdokumentumból és kapcsolódó mellékletekből áll (adattárak, térképek, nyilvántartások). A települési veszélyelhárítási terv elkészitése során a polgármester bevonja az adott elem tekintetében a feladat- és hatáskörrel rendelkező illetékes szervet. A polgármester a települési veszélyelhárítási tervben foglaltak végrehajtásának biztosítására legalább 3 évente gyakorlatot tart. A települési veszélyelhárítási tervet a helyi védelmi bizottság hagyja jóvá a katasztrófavédelmi kirendeltség egyetértésével. A települési veszélyelhárítási terv mellékletét képezi a külső védelmi terv és a helyi vízkárelhárítási terv. A polgármester a jóváhagyott veszélyelhárítási terv egy példányát megküldi a katasztrófavédelmi kirendeltségnek.

A terv alapdokumentum kapcsolódó mellékleteket tartalmaz. Kockázatelemzés és -értékelés alapján a kimutatott veszélyeztető hatásokra, azok következményeinek elhárítása érdekében készül. Mellékletként tartalmazza a többi között: a külső védelmi tervet, illetve a helyi vízkárelhárítási tervet is. 
Települési veszélyelhárítási terv tartalma:

1. A védekezésben részt vevők:

- irányítás, vezetés, együttmüködés,

- kapcsolattartás és jelentések,

- készenlétbe helyezés, riasztás, kapcsolattartás,

- egyéni védőeszközökkel való ellátás,

- köteles polgárvédelmi szervezetek készenlétbe helyezésének,

- müködéshez szükséges eszközök biztosításának,

- védekezésben részt vevő egyéb szervezetek készenlétbe helyezésének és alkalmazásának logisztikai biztosítása,

- kárterületre való belépés.

2. A lakosság védelme:

- riasztás, figyelmeztetés, veszélyhelyzeti tájékoztatás,

- kitelepítés, kimenekítés, befogadás-elhelyezés, visszatelepítés,

- elzárkóztatás,

- egyéni védőeszközökkel való ellátás,

- mentesítés,

- elsősegélynyújtás, sérültszállítás,

- halálos áldozatokkal kapcsolatos halaszthatatlan intézkedések.

3. Kritikus infrastruktúra-elemek, létfontosságú anyagi javak védelme.

4. Hátrahagyott anyagi javak védelme.

5. Vizek kártételei elleni védekezésben való közremüködés.

6. Menekültek ideiglenes elhelyezésében, ellátásában való közreműködés.

7. Nemzetközi szerződésből adódó tájékoztatás, kölcsönös segítségnyújtás.

8. Ideiglenes helyreállítás, ingatlanok, ingóságok kármentesítése (fertőtlenítése). ${ }^{7}$

\section{Katasztrófavédelmi kirendeltség összesített terve}

Illetékességi területére vonatkozóan a katasztrófavédelmi kirendeltség - a települési szintet meghaladó beavatkozást igénylő katasztrófavédelmi feladatok ellátása érdekében - a települési veszélyelhárítási tervek alapján összesített tervet készít.

\section{Területi (fővárosi) veszélyelhárítási terv}

Területi (fővárosi) veszélyelhárítási tervet készít a megyei, fővárosi védelmi bizottság az illetékességi területén jelentkező veszélyelhárítási feladatok összehangolására a megyei közgyülés elnöke (a fővárosban a főpolgármester), a megyei, fővárosi katasztrófavédelmi igazgatóság közremüködésével. A területi veszélyelhárítási terv alapdokumentumból és kapcsolódó mellékletekből áll (adattárak, térképek, nyilvántartások). A területi veszélyelhárítási tervet a megyei, fővárosi védelmi bizottság

234/2011. (XI. 10.) Korm. rendelet a katasztrófavédelemről és a hozzá kapcsolódó egyes törvények módosításáról szóló 2011. évi CXXVIII. törvény végrehajtásáról. 
hagyja jóvá a BM Országos Katasztrófavédelmi Főigazgatóság (a továbbiakban: BM OKF) főiigazgatójának egyetértésével.

\section{Központi veszélyelhárítási terv}

Központi veszélyelhárítási tervet készít a BM OKF főigazgatója a katasztrófaveszély elhárítására és a katasztrófa következményeinek lehető legkisebbre csökkentésére. A központi veszélyelhárítási terv különösen az alábbiakat tartalmazza:

- az emberi élet, a létfenntartáshoz szükséges anyagi javak védelme,

- a kritikus infrastruktúrák védelme,

- a lakosság alapvető ellátásának biztosítása.

A központi veszélyelhárítási tervet a katasztrófák elleni védekezésért felelős miniszter hagyja jóvá. Katasztrófaveszély esetén a BM OKF főigazgató e terv alapján az életés anyagi javak védelme, súlyos károk megelőzése érdekében intézkedések bevezetésére jogosult.

Összességében tehát megállapítható, hogy a települések katasztrófavédelmi besorolási rendszerének megújulásával a veszélyhelyzeti tervezés rendszere is alapvetően átalakul. A besorolt településeken a polgármester gondoskodik - az adott településre készített kockázatelemzés és értékelés alapján kimutatott veszélyeztető hatásoknak és a következményei elhárítása érdekében meghatározott elégséges védelmi szintnek megfelelő - települési veszélyelhárítási terv elkészítéséről. A terület újraszabályozása, a megváltozott követelményekhez való igazítása költségtakarékossá teszi a védelmi tervezést, mert az konkrét veszélyeztető hatásokra épül, továbbá kiszámíthatóbbá teszi a gazdasági-anyagi szolgáltatások teljesítésére kötelezettek terheit a pontosan tervezhető költségek tekintetében. A veszélyelhárítási terv a katasztrófaveszély, valamint a katasztrófa időszakában végrehajtandó katasztrófavédelmi feladatokat tartalmazó dokumentum, települési, megyei és országos szintre kidolgozva.

A Kat. hatálybalépésével létrejövő közbiztonsági referensi rendszer is a települések katasztrófavédelmi osztályba sorolásához kötődik. A Kat. vhr. alapján az I. és II. osztályba sorolt településeken a polgármester kijelöli a referens személyét és biztosítja a képzéseken történő részvételét, amely mintegy 1000-1100 fős létszámot jelent.

A jogszabályok, a Jelentés Magyarország nemzeti katasztrófakockázat-értékelési módszertanáról és annak eredményeiröl címủ dokumentum és a jelentés elfogadását követően elkészített útmutató felhasználásával a települési besorolások megfelelő alapot adnak az elégséges védelmi követelmények meghatározásához, a veszélyelhárítási tervek elkészítéséhez, a katasztrófák elleni védekezés során mind a megelőzés, mind a beavatkozás, mind az újjáépítés megszervezéséhez és végrehajtásához.

A katasztrófavédelem korábbi jogszabályi környezetének átfogó módosításával, az állam szerepvállalásának növelésével fokozhatóvá vált Magyarország területén a lakosság életének, vagyonának biztonsága, valamint megoldhatóbbá az ország müködőképességének folyamatos fenntartása. ${ }^{8}$

8 Muhoray Árpád: A 2001-es beregi árvíz tizedik évfordulóján túl, Belügyi Szemle, 60 (2012/9) 107-123. 


\section{Az önkormányzati tüzoltóságok müködése}

Az önkormányzati tüzoltóságok müködését a tüz elleni védekezésről, a müszaki mentésről és a tüzoltóságról szóló 1996. évi XXXI. törvény határozza meg - csakúgy, mint a hivatásos, a létesítményi tüzoltóságok, valamint önkéntes tüzoltó egyesületek esetében, emiatt a szabályozás általánosan vonatkozik mindegyik „típusra”, azok nem szétválaszthatók, de kiemelem azokat az előírásokat, amelyek különösen fontosak a téma vizsgálata szempontjából.

A törvény részletesen szabályozza azokat a jogosultságokat, amelyeket a tüzoltásban részt vevőknek biztosít, különös tekintettel a tűzoltásvezetőkét, például korlátozhat, bevonhat másokat a feladat végrehajásába.

A törvény hatálya mindenkire kiterjed, aki Magyarország területén tartózkodik, így bárki bevonható képességeihez mérten, de magát a tüzoltást, a müszaki mentést végző rendszer müködtetését és fenntartását állami feladatként jelöli meg (lévén a védelmi igazgatás rendszerébe tartozik, aminek fenntartása állami feladat).

A helyi önkormányzatoknak vannak az általuk létrehozott és fenntartott tüzoltósággal kapcsolatos feladataik, amelyek a következők:

- hozzájárulhatnak a hivatásos tűzoltóság, valamint hozzájárulnak - ha van a területükön müködő - az önkormányzati tüzoltóság és az önkéntes tűzoltó egyesület fenntartásához;

- gondoskodnak az önkormányzati tüzoltóság fenntartásáról, müködtetéséről és fejlesztéséhez;

- hozzájárulhatnak más tűzoltóság létesítéséhez, fenntartásához, fejlesztéséhez;

- az önkormányzati képviselő-testületek elrendelhetik az irányításuk alá tartozó önkormányzati tüzoltóságok rendkívüli készenléti szolgálatát;

- az önkormányzati képviselő-testületek beszámoltatják az önkormányzati tüzoltóparancsnokokat;

- megszüntethetik az önkormányzati tüzoltóságot, de mielőtt ezt megtennék, fél évvel a megszüntetés dátumánál korábban tájékoztatniuk kell erről a belügyminisztert.

Ezenfelül a képviselő-testületek elrendelhetik az irányításuk alá tartozó tüzoltóságok számára a rendkívüli készenléti szolgálatot, valamint a Belügyminisztérium tájékoztatása mellett megszüntethetik az önkormányzati tüzoltóságot.

Az önkormányzati tűzoltóságok létesítésével, fejlesztésével, működésével és fenntartásával kapcsolatos költségeket egymás közt arányosan osztja fel a székhely szerinti települési önkormányzat, az elsődleges műveleti körzete szerinti települések önkormányzatai, valamint a központi költségvetés. A központi költségvetés által az önkormányzati tủzoltóságok részére biztosított összeg nagyságát meghatározza az önkormányzati tűzoltóság vonulási területének reális veszélyeztetettségét kifejező pontszám, ${ }^{9}$ valamint az állam az önkormányzati tǔzoltóságok müködéséhez évente 25 millió forinttal járul hozzá, illetve a támogatások felosztása után az előirányzatból

\footnotetext{
9 Ez a veszélyeztetettségi pontszám, amelyet a 239/2011. (XI. 18.) Korm. rendelet 13. §-a alapján határoznak meg.
} 
megmaradó pénzösszeg is az önkormányzati tűzoltóságokhoz kerül, azok veszélyeztetettségi pontszáma alapján. ${ }^{10}$

A 39/2011. BM rendelet a tüzvédelmi törvénynél sokkal bővebben ismerteti a tüzoltásban és müszaki mentésben részt vevők feladatait, kötelezettségeit, jogait, valamint a mentő tűzvédelem különböző szakaszait.

Ami kiemelendő a rendeletből az az, hogy a tűzoltás, műszaki mentés vezetését ki végezheti az önkormányzati tüzoltóságoknál: rajparancsnok, parancsnokhelyettes, parancsnok. A rendelet meghatározza a tűzoltásvezetés átadás-átvételének sorrendjét, így:

- a beavatkozó önkéntes tüzoltó-egyesülettől átveszi az önkormányzati vagy hivatásos tüzoltóság,

- a nem főfoglalkozású létesítményi tűzoltóságtól átveszi az önkormányzati tüzoltóság,

- az önkormányzati tüzoltóságtól átveszi a hivatásos tüzoltóság,

- a főfoglalkozású létesítményi tüzoltóságtól átveszi a hivatásos tüzoltóság.

Tüzoltásvezetői feladatokat csak úgy lehet ellátni, ha az illető rendelkezik a törvényben meghatározott képesítéssel, iskolai végzettséggel. Az önkormányzati tűzoltóságok esetében ez a Katasztrófavédelmi Oktatási Központ által lebonyolított képzéseket, vagy azokkal egyenértékü közép- vagy felsőszintű képzéseket követően lehetséges. ${ }^{11}$

A 48/2011. (XII. 15.) BM rendelet határozza meg az önkormányzati tüzoltóságok legkisebb létszámát, létesítményei és felszerelései minimális mennyiségét, minőségét, valamint szolgálati ellátását. Ebben rögzítették, hogy az önkormányzati tüzoltóság legkevesebb 4 fővel adhat készenléti szolgálatot, amelyben a híradóügyeletet adó személy is vonultatható. Ilyenkor a híradóügyelet szüneteltethető. A riasztást ${ }^{12}$ követően 8 percen belül kell megkezdeniük a vonulást.

Állományát tekintve vegyesen állhat főfoglalkozású vagy önkéntes jogviszonyban álló önkormányzati tűzoltókból. ${ }^{13}$ Ezeken felül az önkormányzati tűzoltóságoknak is gondoskodniuk kell a szolgálatszervezésről, valamint az éves továbbképzési tervről.

Az önkormányzati és létesítményi tűzoltóságokra, valamint a hivatásos tűzoltóság, önkormányzati tűzoltóság önkéntes tüzoltó egyesület fenntartásához való

2018. évi L. törvény Magyarország 2019. évi központi költségvetéséröl 44. §.

„[...] minimum tủzoltó II. részszakképesítéssel - vagy annak megfelelő, e rendeletben elismerhető szakmai képesítéssel, - a képesítés megszerzésétől számított minimum 5 éves, hivatásos, önkormányzati, vagy föfoglalkozású létesítményi tủzoltóságnál szerzett tűzoltási, müszaki mentési gyakorlattal, továbbá tủzoltásvezető I. tanfolyammal". 9/2015. (III. 25.) BM rendelet a hivatásos katasztrófavédelmi szerveknél, az önkormányzati és létesítményi tűzoltóságoknál, az önkéntes tüzoltó egyesületeknél, valamint az ez irányú szakágazatokban foglalkoztatottak szakmai képesítési követelményeiről és szakmai képzéséről 17 . § b) pont.

12 A riasztás közvetlenül az önkormányzati tűzoltóságra érkezhet (erröl azonnal tájékoztatnia kell a megyei műveletirányítást), ha a segélyhívás vagy jelzés odaérkezik, illetve a megyei műveletirányítástól kaphatják, ha a hívás a 112-re fut be.

13 Mind a föfoglalkozású, mind pedig az önkéntes jogviszonyban álló önkormányzati tűzoltónak be kell töltenie a szolgálat ellátásához a 18. életévét, és pszichikai, fizikai egészségügyi alkalmassági vizsgálaton kell átesnie, de a képzettségi szintjük eltérő. A föfoglalkozásúnak a Katasztrófavédelmi Oktatási Központban kell képesítést szereznie, az önkéntes jogviszonyban állónak 40 órás tűzoltó alaptanfolyamon kell „megfelelő" minősítéssel vizsgáznia: 9/2015. (III. 25.) BM rendelet a hivatásos katasztrófavédelmi szerveknél, az önkormányzati és létesítményi tủzoltóságoknál, az önkéntes tűzoltó egyesületeknél, valamint az ez irányú szakágazatokban foglalkoztatottak szakmai képesítési követelményeiről és szakmai képzéséröl, 5 . § és 1 . melléklet. 
hozzájárulásra vonatkozó szabályokról szóló 239/2011. (XI. 18.) Korm. rendeletben határozzák meg, hogy az önkormányzati tűzoltóparancsnokságok (ÖTP-k) vonulási területeit, amely szerint a riasztott erők legfeljebb 25 percen belül érjenek a helyszínre a jelzés vételétől, vagy ha több mint 25 perccel később ér a helyszínre, de hamarabb, mint a hivatásos tủzoltóság, akkor a kérdéses terület csatolható az önkormányzati tüzoltóság vonulási területéhez.

A rendelet alapján az önkormányzati tüzoltóságnak a magalakulást követő 30 napon belül együttmüködési megállapodást kell kötnie az illetékes katasztrófavédelmi kirendeltséggel, amelyet a megyei katasztrófavédelmi igazgatóság vezetője hagy jóvá.

Az együttmüködési megállapodásnak tartalmaznia kell a felek nevét, székhelyét, a kapcsolattartók nevét, elérhetőségét, a vonulási területet, a készenléti létszámot, a riasztható eszközöket és felszereléseket, valamint az együttmüködési megállapodás megszűnésének eseteit. Megszűnésre okot adó körülmény általában, ha az egyik fél jogutód nélkül megszűnik, vagy ha az önkormányzati tủzoltóság nem tudja a vállalt feladatát ${ }^{14}$ teljesíteni és emiatt a megállapodás megszüntetését kéri.

Az önkormányzati tủzoltóságok szakmai felügyeletéről és ellenőrzéséről a tüz elleni védekezésről, a műszaki mentésről és a tűzoltóságról szóló 1996. évi XXXI. törvény egyes részei szólnak.

Az önkormányzati tủzoltóság parancsnokát a települési önkormányzat képviselőtestülete évente beszámoltatja az elvégzett feladatokról, a vonulási terület tűzvédelmi helyzetéről.

A BM OKF koordinálja és ellenőrzi az önkormányzati tüzoltóságok költségvetéstervezésével kapcsolatos feladatait, valamint a területi szerv útján folyamatosan ellenőrzi a költségvetési és egyéb forrásból származó pénzeszközei felhasználását. ${ }^{15}$ Az önkormányzati tűzoltóság fennmaradásának és müködésének rendkívüli költségeit szintén a hivatásos katasztrófavédelmi szerv központi szerve finanszírozza egy erre félretett alapból.

A BM OKF és a megyei (fövárosi) katasztrófavédelmi igazgatóság a katasztrófavédelmi kirendeltségek szervezetébe tartozó hivatásos tüzoltó-parancsnokságok útján ellenőrzi a parancsnokság területén müködő önkormányzati tüzoltóság egészét: a feladatok ellátását, az ahhoz szükséges személyi és technikai feltételeket, valamint az oktatást. Amennyiben az ellenőrzés során hiányosságot tárnak fel, pótlásra hívja fel a figyelmet a hivatásos szerv. Amennyiben az önkormányzati tűzoltóság egyáltalán nem vagy nem megfelelően intézkedik a hiányosság pótlására, a BM OKF a feladatellátási-képesség csökkenésével arányos módon csökkenti az általa biztosított költségfedezetet.

A fentiek alapján úgy tünik, az önkormányzati tüzoltóságok „helyileg” a hivatásos tủzoltóság és az önkéntes tűzoltó-egyesületek között vannak: fenntartásuk, működtetésük egy része állami kézben van, de ugyanolyan mértékben a létesítő

A vállalt feladat mentő tủzvédelmi tevékenység és ezzel kapcsolatos feladatok végrehajtását, valamint biztonsági intézkedések végrehajtásában történő közreműködést takar.

15 Az önkormányzati tüzoltóságok pályázati úton kaphatnak az országos és az illetékes területi katasztrófavédelmi szervtől pályázati úton, valamint egyedi elbírálás alapján pénzbeli és nem pénzbeli juttatást. Ezenkívül a fenntartás és müködés költségeit is vállalja az önkormányzati tűzoltóság által elvégzett feladattal arányosan: 1996. évi XXXI. törvény a tűz elleni védekezésről, a müszaki mentésröl és a tűzoltóságról 34. § (4) bek.; 41. § (5) bek. 
önkormányzatéban is. Feltehető a kérdés: kinek az elvárásait kell az önkormányzati tüzoltóságnak elörébb sorolnia: az államét vagy az önkormányzatét? A személyi állomány is ugyanilyen kettős: vannak föfoglalkozásúak és önkéntesek.

Ebben az esetben nem lehet kérdés, hogy - a képesítési feltételeket ismerve a főfoglalkoztatásúak a képzettebbek, felkészültebbek. De az ő esetükben is felmerül: ha az önkormányzati tủzoltóság legmagasabb tisztségeihez is néhány személy megszerezte a képzettséget, hogyan fejleszthető a már megszerzett tudás még tovább.

A kettősség miatt felmerül még, hogy az önkormányzatnak joga van bármikor megszüntetni az általa létrehozott és „félig" fenntartott önkormányzati tüzoltóságot, ezzel szemben a hivatásos katasztrófavédelmi szervnek nincs ilyen lehetőség a kezében.

De ha az általa végrehajtott ellenörzések során olyan müködési, fenntartási vagy egyéb hibát tár fel, és azt az érintett önkormányzati tüzoltóság - súlyosabb esetben az önkormányzat bevonásával - sem tudja kezelni, akkor a megszüntetés vagy önkéntes tủzoltó egyesületté válás lehet a megoldás.

Ezek olyan felvetések, amelyeket meg kellene válaszolni, hiszen ha a védelmi igazgatás gépezetének be kell indulnia, nem mindegy, hogy az önkormányzati tüzoltóságokat hogyan alkalmazzák.

\section{Felhasznált irodalom}

Jelentés Magyarország nemzeti katasztrófakockázat-értékelési módszertanáról és annak eredményeiröl, 2014.

Bognár Balázs - Kátai-Urbán Lajos - Kossa György - Kozma Sándor - Szakál Béla - Vass Gyula: Iparbiztonságtan I. Kézikönyv az iparbiztonsági üzemeltetői és hatósági feladatok ellátásához, Nemzeti Közszolgálati Egyetem, Budapest, 2013.

Muhoray Árpád: A 2001-es beregi árvíz tizedik évfordulóján túl, Belügyi Szemle, 60 (2012/9) 107-123.

Muhoray Árpád: A katasztrófavédelem aktuális feladatai, Tanulmány, 2012, http:// mhtt.eu/hadtudomany/2012/2012_elektronikus/2012_e_Muhoray_Arpad.pdf (Letöltve: 2018. 12. 10.)

\section{Jogi források}

1996. évi XXXI. törvény a tűz elleni védekezésről, a műszaki mentésröl és a tüzoltóságról 2011. évi CXXVIII. törvény a katasztrófavédelemről és a hozzá kapcsolódó egyes törvények módosításáról

2018. évi L. törvény Magyarország 2019. évi központi költségvetéséről

114/1995. (IX. 27.) Korm. rendelet a települések polgári védelmi besorolásáról és a védelmi követelményekröl

234/2011. (XI. 10.) Korm. rendelet a katasztrófavédelemről és a hozzá kapcsolódó egyes törvények módosításáról szóló 2011. évi CXXVIII. törvény végrehajtásáról 
239/2011. (XI. 18.) Korm. rendelet az önkormányzati és létesítményi tűzoltóságokra, valamint a hivatásos tűzoltóság, önkormányzati tűzoltóság és önkéntes tűzoltó egyesület fenntartásához való hozzájárulásra vonatkozó szabályokról

39/2011. (XI. 15.) BM rendelet a tűzoltóság tűzoltási és műszaki mentési tevékenységének általános szabályairól

48/2011. (XII. 15.) BM rendelet az önkormányzati tüzoltóságok legkisebb létszámáról, létesítményei és felszerelései minimális mennyiségéröl, minőségéröl és a szolgálati ellátásáról

6. számú melléklet a 314/2005. (XII. 25.) Korm. rendelethez, A környezeti hatástanulmány általános tartalmi követelményei

8/2014. (III. 21.) BM OKF utasítás az önkormányzati tüzoltó-parancsnokságok szakmai irányításáról és felügyeleti ellenőrzésének rendjéről. [módosította: 10/2018. (X. 4.) BM OKF utasítás]

9/2015. (III. 25.) BM rendelet a hivatásos katasztrófavédelmi szerveknél, az önkormányzati és létesítményi tűzoltóságoknál, az önkéntes tűzoltó egyesületeknél, valamint az ez irányú szakágazatokban foglalkoztatottak szakmai képesítési követelményeiröl és szakmai képzéséről 